\title{
Antifungal effects of Curcuma longa L. essential oil against pathogenic strains isolated from indoor air
}

\author{
Erasmo Gámez-Espinosa (1) Matilde Anaya - Pedro Borges - Diana Marelys Bosch Crespo
}

Received: 26 August 2019/Accepted: 3 November 2020

(C) Springer Nature B.V. 2020

\begin{abstract}
Curcuma longa L. essential oil can be considered a natural product with strong antifungal activity due to the fungicidal and fungistatic effect. It can be used for the aeromycological control of premises where food is prepared. It is important to monitor air quality in food production facilities to achieve safe food. The objective of this work was to evaluate the antifungal activity of $C$. longa essential oil on potentially pathogenic and biodegradable strains isolated from the indoor of the food industry. A suspension of $10^{6}$ spores $/ \mathrm{mL}$ of the strains Aspergillus flavus, Penicillium brevicompactum and Cladosporium cladosporioides was prepared. Two
\end{abstract}

Erasmo Gámez-Espinosa and Matilde Anaya have contributed equally to this work.

E. Gámez-Espinosa ( $₫)$

Centro de Investigación y Desarrollo en Tecnología de

Pinturas (CONICET-CICPBA-UNLP), Ave 52 entre 121

y 122, La Plata, Buenos Aires, Argentina

e-mail: e.gamez@cidepint.ing.unlp.edu.ar

\section{Anaya}

Grupo Empresarial de la Industria Alimentaria, Ave. La Pesquera y Atares, Habana Vieja, La Habana, Cuba

\section{P. Borges}

Instituto de Investigaciones para la Industria Alimentaria, Guatao km 3 1⁄2, Lisa, La Habana, Cuba

D. M. Bosch Crespo

Universidad de Salamanca, Patio de las Escuelas 1,

Salamanca, Castilla y León, España natural biocides (C. longa essential oil and Cuban propolis) and two synthetic ones (antiseptic detergent and Tween 20) at different concentrations (0, 0.001, 0.1 and $1.0 \% \mathrm{v} / \mathrm{v})$ were evaluated. The superficial growth of the mycelium $(\mathrm{cm})$ and the germination inhibition (\%) were the response variables. In addition, the minimum inhibitory concentration (MIC) of EO was determined by radial growth total inhibition (IRG) and partial sporulation inhibition (PIS). A. flavus colony diameter was decrease inversely proportional to the concentrations, and at $1 \% \mathrm{v} / \mathrm{v}$ it reduced more than three times its diameter, being selected as MIC since it caused IRG and PIS. Germination inhibition of the spores of the three strains was observed in relation directly proportional to the concentration of the four biocides. All spores with values similar to antiseptic detergent were inhibited by the essential oil at MIC (1\%) between 41 and $55 \%$

Keywords Antifungal activity · Essential oil · Aeromycology $\cdot$ Indoor environments

\section{Introduction}

Bioaerosols are mainly composed of fungal particles, bacteria and plant pollen grains, fungi being responsible for the release mycotoxins into indoor 
environments (Malta-Vacas et al. 2012). Filamentous fungi manifest the highest biodeteriorating activity of organic matter due to their exoenzymatic activity (Anaya et al. 2016; Rojas and Aira 2012), which is why they are capable of degrading raw materials and finished products of food industry (Jay et al. 2005). This is why the aeromycological control of food processing areas is important. It is necessary to maintain the premises with a relative humidity and low temperature, to control the fungal concentration of the air which prevent the microbiological contamination foods. This can be achieved with the use of dehumidifiers and the installation of air conditioners (Anaya et al. 2019). People spend $80-90 \%$ of their daily time in indoor environments, which requires regular monitoring of indoor air quality (Naddafi et al. 2019). Currently, expensive methods are used and sometimes are not feasible due to the use of chemical substances that are toxic for people and can affect food. Therefore, the application of products obtained from plants (extracts and essential oils) to avoid the biodeterioration of food is presented as a viable solution. It shows advantages from the economic, environmental and it turns out to be an ecological solution that favors the reduction of the use of toxic and polluting chemical substances for the environment (Tyagi et al. 2012). In this sense, essential oils are considered a promising option (Baser 2010; Zorzi Tomazoni et al. 2018) since they do not affect the sensory characteristics of food (Desam et al. 2017), although the minimum inhibitory concentration on genera or the most common fungal species should be studied (Homa et al. 2015). Naturally occurring compounds, such as essential oils from plants, possess antifungal activity. Reports on the fungicidal and fungistatic activities of essential oils have shown that many of the oils are indeed potent inhibitors of fungal growth (H. Wang et al. 2018). Hydroalcoholic solutions of clove essential oil on fungal strains (Aspergillus niger, Aspergillus flavus, Aspergillus fumigatus, Penicillum sp. and Trichoderma sp.) isolated from food stores have shown biocidal action. Inhibitory effect on the superficial growth and / or sporulation of the strains has been evidenced at different concentrations. The dilution method was used in wells, and inhibition was observed superior to miconazole (positive control), possibly due to the presence of eugenol in its composition (Valdés-Pérez et al. 2016).
Curcuma longa $\mathrm{L}$. is known to have many pharmacological activities. This rhizome has the rich content in curcuminoids which curcumin is the main active component (Windarsih et al. 2019). But an essential oil is required that does not provide an odor to food, such as that of $C$. longa that has an antifungal and antimicrobial effect at low concentrations (Homa et al. 2015; Jain and Parihar 2018) and is non-toxic (Mishra et al. 2018). It was evaluated with satisfactory results against the fungal species Fusarium oxysporum, Alternaria dianthi and Curvularia trifolii, obtained both by vacuum distillation and by conventional distillation at atmospheric pressure (Dharmawan et al. 2007). Therefore, the objective of this work was to evaluate the antifungal activity of Curcuma longa $\mathrm{L}$ essential oil for its potential use in the control of air quality in indoor environments.

\section{Materials and methods}

\subsection{Selection of study strains}

The strains selected for this study were Aspergillus flavus Link (Fig. 1), Penicillium brevicompactum Dierckx and Cladosporium cladosporioides Fresen. These strains have the highest frequency and relative density of appearance in the aeromycological studies carried out in indoor environments where food is prepared in the Instituto de Investigaciones para la Industria Alimentaria, Cuba (Anaya et al. 2014). These premises were the central warehouse, the chocolate production area and the products area for

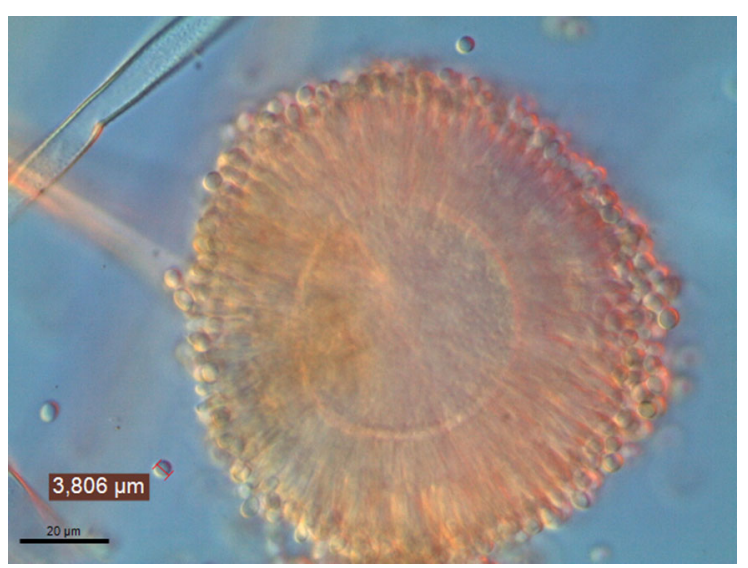

Fig. 1 Conidiophore and conidia of A. flavus Link. 640x 
special regimes, which are a representation of the Cuban food industry.

\subsection{Biocides}

Curcuma longa essential oil (EO) obtained from the dried rhizome of the plant was used by hydrodistillation, using a laboratory distiller and a Clevenger type trap (ISO 1984). In addition, they were compared with other biocides to assess the potentialities of the EO evaluated. These were Cuban propolis of Apis mellifera L., since it is suggested that this natural product has antifungal activity (Campos 2007; Quintero-Mora et al. 2008) and two synthetic ones that were an antiseptic detergent (Deconex) and a surfactant (Tween 20). Four concentrations $(0,0.001,0.1$ and $1.0 \% \mathrm{v} / \mathrm{v}$ ) of each biocide were evaluated.

\subsection{Effect on germination of spores}

Each strain was inoculated in culture tubes with $15 \mathrm{ml}$ of malt extract agar. They were incubated at $30{ }^{\circ} \mathrm{C}$ for 10 days, and then, $20 \mathrm{ml}$ of a $0.1 \%(\mathrm{v} / \mathrm{v})$ Tween 80 solution was added. The obtained mixture was filtered through a sterile gauze to remove the mycelia. A standardized suspension of $10^{6}$ spores $/ \mathrm{ml}$ was prepared counting in the Neubauer chamber (ValdésPérez et al. 2016). In a 96-well plate, $10 \mu \mathrm{L}$ of the spore suspension and the biocides were added at different concentrations. The germination of the spores was evaluated at $24 \mathrm{~h}$, counting 200 spores in each well with the help of an optical microscope. Germination inhibition was expressed as a percentage (\%) of the ungerminated spores with respect to the total (Levinskaite 2012). The death of the spores was confirmed by flow cytometry.

\subsection{Effect on radial growth of mycelium in fungal strains}

To analyze the effect of the essential oil on the radial growth of the mycelium, the strain of A. flavus was selected because it was considered a potentially pathogenic (Mutua et al. 2019; Sabino et al. 2019). It is evidenced the potential of this natural antifungal from the resistance of the pathogenic strains as a evolutionary adaptation. Aspergillus flavus is a common opportunistic pathogen causing human infections and is involved in the production of aflatoxin and other secondary metabolites associated with toxic and allergic reactions (Malta-Vacas et al. 2012). In addition, strain has high radial growth velocity in solid medium which facilitated the measurement of the colony diameter. It was taken as indicative of the effectiveness of the oil since its action is dependent on the interaction time.

A roast was taken from the edge of the sporulated strain, which grew in a culture tube which contained Czapek agar and was inoculated by puncture on the Petri dishes with the same culture medium. The $C$. longa essential oil solution was added at the concentrations described in the previous experiment. The plates were incubated at $30{ }^{\circ} \mathrm{C}$ for 7 days, at which time the radial growth was quantified from the colony diameter measurement $(\mathrm{cm})$ (Quintero-Mora et al. 2008).

In this study, the minimum inhibitory concentration (MIC) was the lowest concentration of antifungal against which growth was affected (Levinskaite 2012) of the strain of A. flavus whose criterion was the appearance of radial growth total inhibition (IRG) and partial inhibition of sporulation (PIS). In all the experiments, growth was taken on Petri dishes with Czapek Agar free of essential oil.

\subsection{Statistic analysis}

Each treatment was performed in triplicate. The statistical analysis of the data of the response variables was carried out with the Statgraphics Centurion XV program. The probability distribution was analyzed with the chi-square normality test, ANOVA was performed, and Fisher's minimal significant difference method (LSD) was applied.

\section{Results and discussion}

The effect observed on these two phases of the biological cycle (radial growth and conidiogenesis) also implies an affectation in the germination of the inoculated conidia.

In this sense, the influence of the types of biocide and its concentrations on this variable were shown, whose values had a normal distribution and with a statistically significant difference $(p \leq 0.05)$ (Fig. 2). A. flavus, $P$. brevicompactum and $C$. cladosporioides were of same concentrations and the germination 

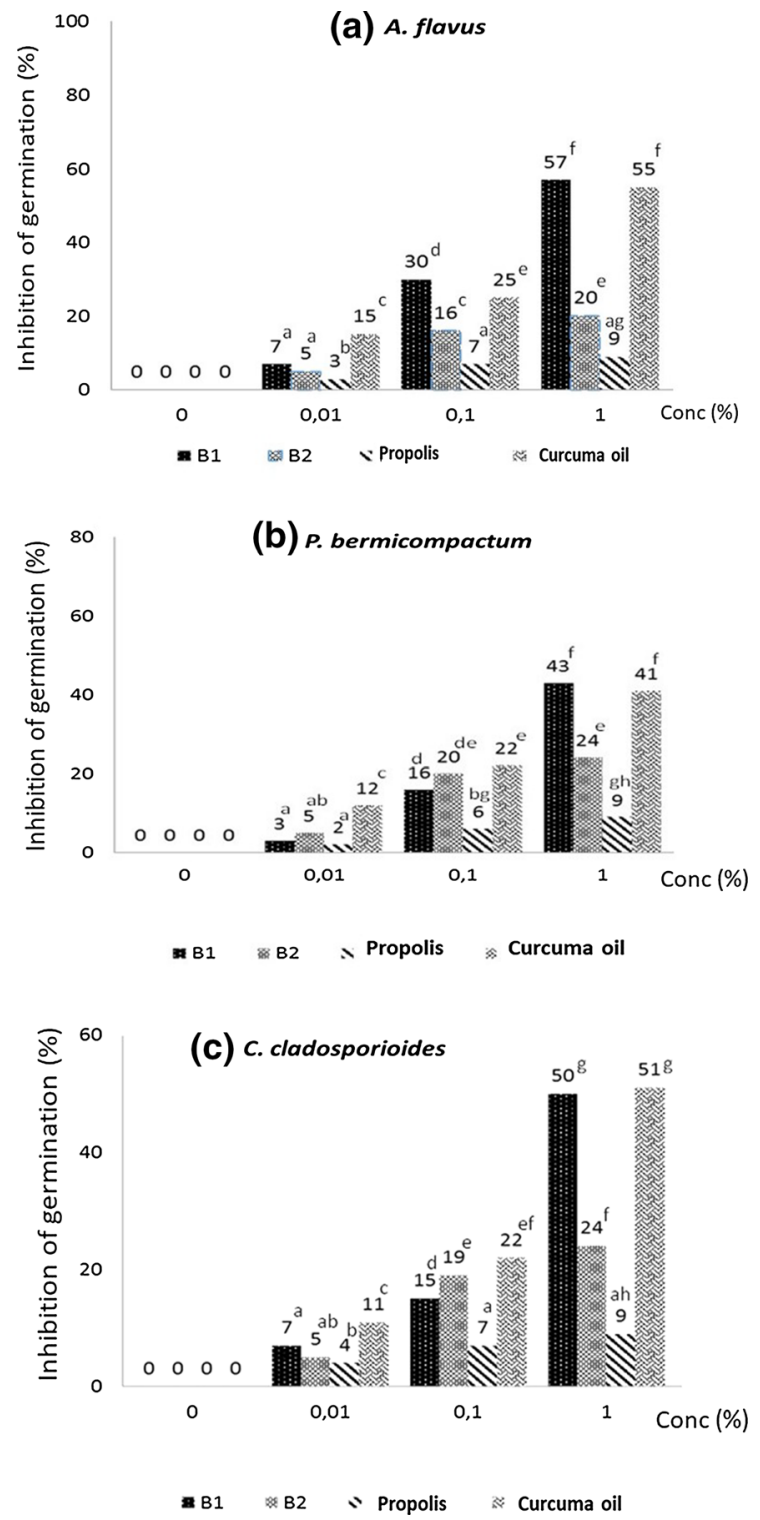

Fig. 2 Germination inhibition by the effect of Deconex antiseptic detergent (B1), Tween 20 (B2) surfactant, Cuban propolis and $C$. longa essential oil. $\mathrm{t}=24 \mathrm{~h}$. a A. flavus, $\mathbf{b} P$. brevicompactum and c $C$. cladosporioides. Different letters indicate statistically significant differences $(p \leq 0.05)$ for $\mathrm{n}=96$ and for Fisher's LSD

inhibition showed a directly proportional relationship. That is, the spores germinated less when the concentration of the biocide was stronger. It was observed that of the two synthetic products the commercial detergent had greater effect than the Tween 20 surfactant. However, with the maximum value of this factor propolis only inhibited $13 \%$, while the rest was between 29 and 95\%. The results obtained with Cuban propolis were contrary to those reported by other authors who stated that this compound has a high antifungal activity (Campos 2007; ISO 1984; Quintero-Mora et al. 2008). For all the biocides, at $1 \% \mathrm{v} / \mathrm{v}$ the affectation in the germination of the conidia of the fungal species was observed in decreasing order: $A$. flavus, $P$. brevicompactum and $C$. cladosporioides. This could be related to the morphology of their conidia (A. flavus: spherical $3.5 \mu \mathrm{m}$ in diameter, $P$. brevicompactum: ellipsoidal $2.5 \times 3.5 \mu \mathrm{m}$, C. cladosporioides: ellipsoidal from 2 to $6 \times 5$ at $10 \mu \mathrm{m}$ ) (Restrepo et al. 2012). In that sense, the greatest influence is given by the size that has a reverse order to that mentioned since the spores of the last species are double the size of the first two.

The essential oil of C. longa at the MIC (1\% v/v) inhibited between 41 and 55\% of the spores of the three strains, similar values to those of the commercial Deconex detergent. Concentrations of ten and one hundred times lower (0.01 and $0.1 \%$ ) did not exceed $30 \%$ of the inhibition but significantly exceeded the aforementioned synthetic product. This fungicidal effect (affects germination) and fungistatic effect (affects growth and conidiogenesis) shows that this essential oil of a Cuban species can be considered as a natural product with high antifungal activity.

Figure 3 shows the inhibition of A. flavus spores measured by flow cytometry. Figure 3 a shows when the spore solution was free essential oil. It is observed that $99.61 \%$ of the spores are alive due to the absence of the essential oil. In (Fig. 3b), it is noted that $71.44 \%$ of the spores died when was faced with the $1 \%$ essential oil. This confirm the antifungal activity of this natural biocide.

Fungal pathogens are a growing worldwide concern. Declines in several economically and agriculturally important plant and animal species pose a significant threat to both biodiversity and food security. Although many effective antifungal agents have been identified, their toxicity often precludes their use with food products (Gabriel et al. 2018).

Aflatoxins are a group of heterocyclic, oxygencontaining mycotoxins that possess the bisdifurano ring system and are structurally related. These toxins are secondary metabolites which are produced by certain strains of Aspergillus flavus. Aflatoxins $\mathrm{B}_{1}, \mathrm{~B}_{2}$, $\mathrm{G}_{1}$ and $\mathrm{G}_{2}$ are the most commonly encountered forms. Aflatoxins, especially aflatoxin $\mathrm{B}_{1}$, pose a quadruple 

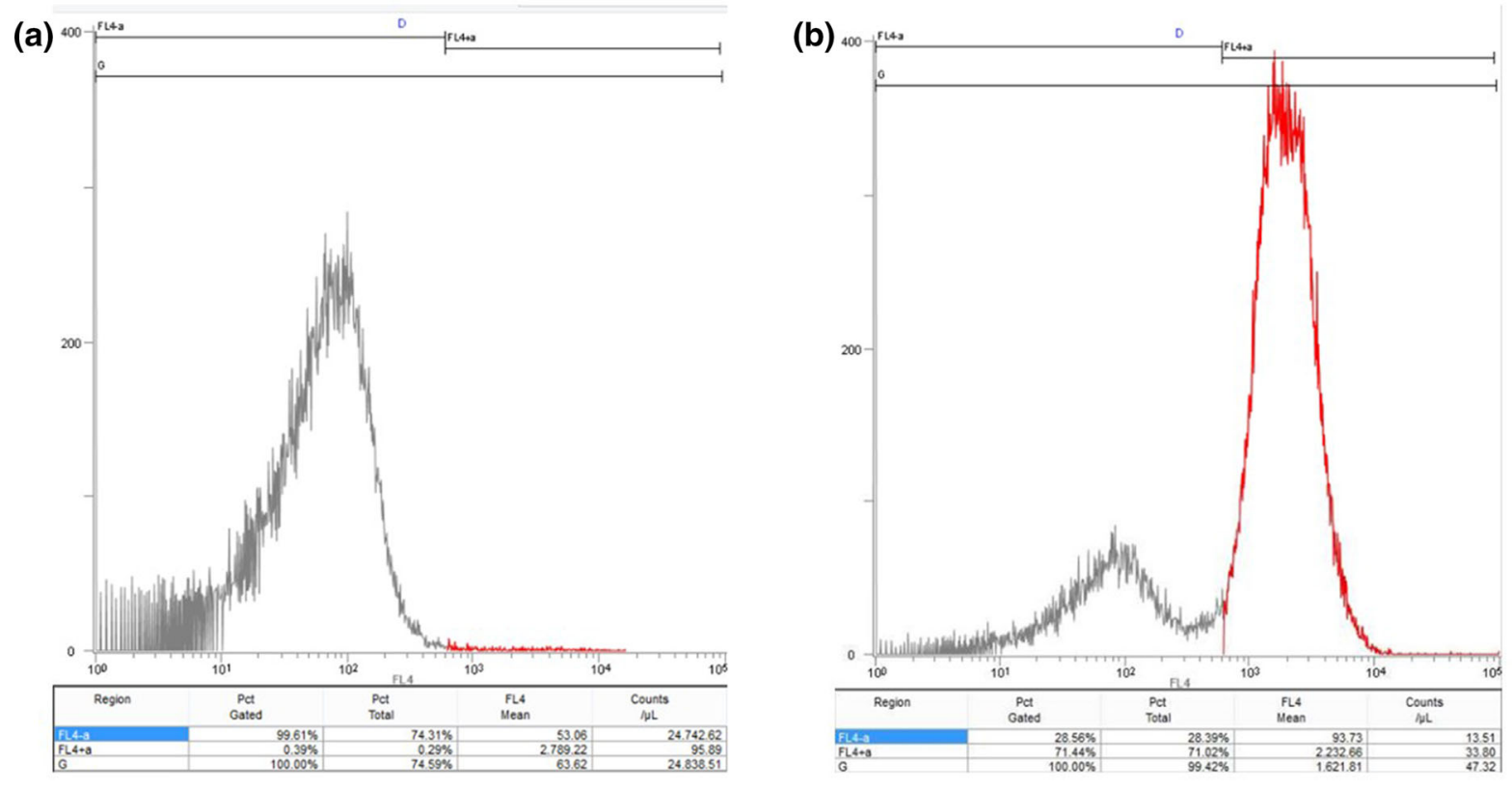

Fig. 3 Germination inhibition in A. flavus measured by flow cytometry. a control (free $C$. longa essential oil). b $C$. longa essential oil (1\%). Gray: alive spores, red: dead spores

threat to both humans and animals as they are toxigenic, carcinogenic, mutagenic and teratogenic. Strains of A. flavus that produce aflatoxins are ubiquitous in nature. Aflatoxins have been frequently detected in grains, oil seeds, tree nuts, fermented beverages made from grains, milk, other edible animal tissues and many commodities. Aflatoxins in animal feeds present a twofold problem: deleterious effects first, on the health of the animal ingesting the contaminated feed, and, second, on the health of humans consuming aflatoxin residues in foods derived from such animals. A. flavus that produce aflatoxins can grow over a wide range of environmental conditions and in the presence of sublethal concentrations of numerous food additives (Wang et al. 2019).

There was a statistically significant difference ( $p \leq 0.05$ ) in the radial growth of A. flavus according to the different concentrations of the essential oil of $C$. longa, with an inversely proportional relation (Fig. 4). This results in a radial growth when the strain is exposed to higher concentrations of the essential oil. This natural product with $1 \%$ concentration reduced more than three times the diameter of the filamentous fungus colony considered potentially pathogenic ( 9 to $2.6 \mathrm{~cm}$ ). In addition, this was selected as the MIC since it caused IRG and PIS (Fig. 5), a result that

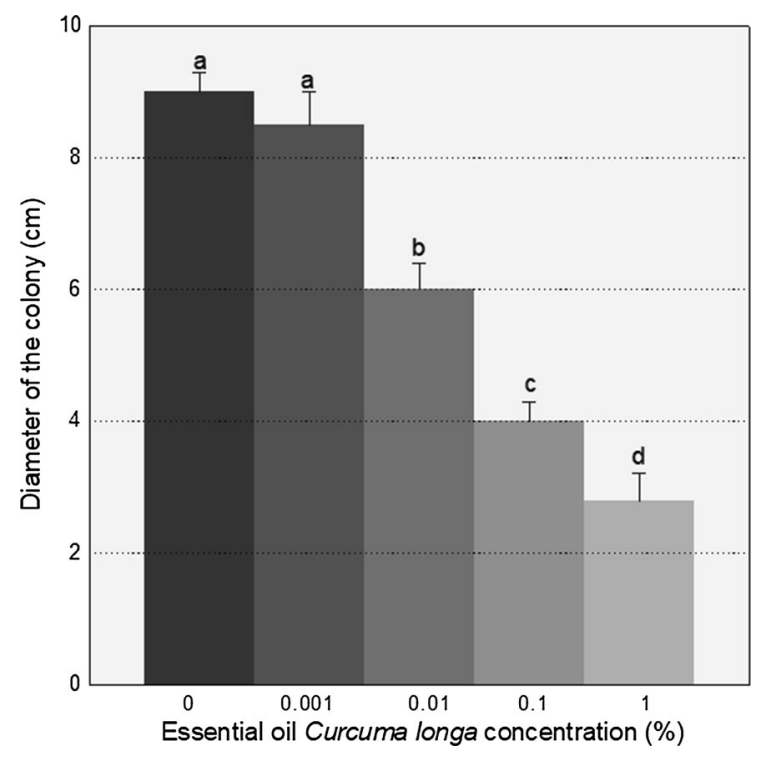

Fig. 4 Radial growth of A. flavus in Czapek Agar with C. longa essential oil. Different letters indicate statistically significant differences $(p \leq 0.05)$ and for Fisher's LSD

agrees with a similar effect of IPE on the A. flavus strain when clove essential oil was applied in the area was affected the conidiogenesis, lack of pigmentation of the conidia or notable absence of these in the 


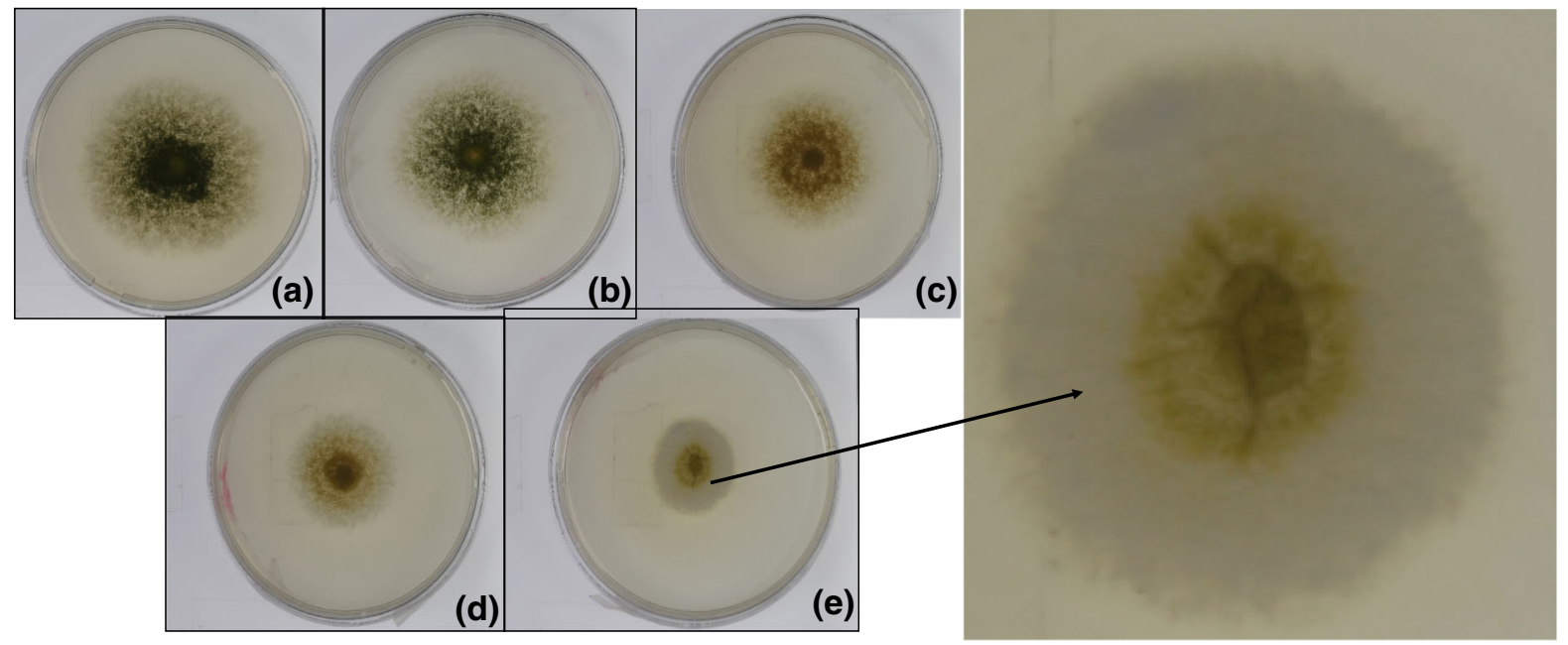

Fig. 5 Effect of $C$. longa essential oil on radial growth the A. flavus. a $0 \%, \mathbf{b} 0.001 \%, \mathbf{c} 0.01 \%, \mathbf{d} 0.1 \%$ and e $1.0 \%$. The arrow indicates the zone of total inhibition of growth and sporulation partial

conidiophores (Hu et al. 2017; Valdés-Pérez et al. 2016).

Polarized apical growth in all filamentous fungi requires vesicular transport for secretion proteins with exoenzyme functions that regulate the control of cell wall synthesis. This metabolic process can be directly affected by phenolic compounds, terpenes, aliphatic alcohols and other substances present in essential oils that inactivate enzymes or alter the structure of the cell membrane (Perczak et al. 2019; Saravia et al. 2013). Therefore, A. flavus strain behavior may be due to the affectations that curcumin could cause the essential oil that penetrated the spores by diffusion. It is proposed that curcumin has proteolytic activity (with timedependent kinetics), attributed to the presence of cysteine-like proteases with a high content of alanine and glutamate, as well as other Ile-Pro and Phe-Leu peptides (Mishra et al. 2018).

To obtain more hygienic indoor air, environments are required antimicrobial surfaces. C. longa essential oil can be incorporated as a biocide in the formulations of hygienic coatings used in indoor environments due to its antifungal activity. Their study is very active at the present, especially the seeking of new eco-friendly bioactive additives or microbiocides to replace those questioned due to their toxicity and low efficiency (Bellotti and Deyá 2019). For example, Fernández et al. (2020), obtained a waterborne acrylic paint functionalized with essential oils capable of inhibiting the growth of A. fumigatus. Another potential use of this biocide is indoor air purification and ventilation systems sanitation. As opposed to most antimicrobial agents currently used for air disinfection, essential oils are low in toxicity (Ji et al. 2019). In a study Pibiri et al. (2006) demonstrated that the gaseous phase of the essential oil of savory has a lethal effect on fungal airborne, and it has a satisfying bacteria reduction rate close to the total disinfection achieved with evaporated formol. It is valid to highlight the limitations that these applications may have. The type of indoor environment (warehouse, food industry, working environments, etc.) must be taken into account. The amount of oil to be deposited must be sufficient for the volume of air in each room. Relative humidity and temperature are factors that must also be taken into account.

\section{Conclusions}

The fungicidal effect (affects germination) and fungistatic effect (affects growth and conidiogenesis) observed in this investigation show that the Curcuma longa $\mathrm{L}$ essential oil can be considered as a natural product of high antifungal activity against the strain of A. flavus considered potentially pathogenic. Furthermore, since it is an odorless compound, it can be used for the aeromycological control of premises where food is prepared since it inhibits the germination of 
fungal strains of high relative frequency of appearance in these indoor environments.

Acknowledgements To Instituto de Investigaciones para la Industria Alimentaria, Cuba for their financial support.

\section{References}

Anaya, M., Borrego, S., Cobo, H., \& Oderlaise Valdés, A. M. (2014). Aeromicobiota de un depósito de alimentos en La Habana Cuba. AUGMDOMUS, 6, 95-110.

Anaya, M., Borrego, S. F., Gámez, E., Castro, M., Molina, A., \& Valdés, O. (2016). Viable fungi in the air of indoor environments of the National Archive of the Republic of Cuba. Aerobiologia, 32(3), 513-527. https://doi.org/10.1007/ s10453-016-9429-3.

Anaya, M., Gámez-Espinosa, E., Falco, A. S., Benítez, E., \& Carballo, G. (2019). Characterization of indoor air mycobiota of two locals in a food industry Cuba. Air Quality, Atmosphere \& Health, 12(7), 797-805. https://doi.org/10. 1007/s11869-019-00707-7.

Baser, K. H. C., \& Buchbauer, G. (2010). Handbook of essential oils: science, technology, and applications. FL, USA: CRC Press. Boca Raton.

Bellotti, N., \& Deyá, C. (2019). Natural Products Applied to Antimicrobial Coatings. In Studies in Natural Products Chemistry (Vol. 60, pp. 485-508). Elsevier B.V. https:// doi.org/10.1016/B978-0-444-64181-6.00014-0

Campos, M. (2007). Estudio químicos de propóleos rojos cubanos. Havana: Univeridad de La Habana.

Desam, N. R., Al-Rajab, A. J., Sharma, M., Mylabathula, M. M., Gowkanapalli, R. R., \& Albratty, M. (2017). Chemical constituents, in vitro antibacterial and antifungal activity of Mentha $\times$ Piperita L. (peppermint) essential oils. Journal of King Saud University - Science. https://doi.org/10.1016/ j.jksus.2017.07.013.

de Saravia, S. G., Borrego, S., Lavin, P., Valdés, O., Vivar, I., Battistoni, P., \& Guiamet, P. (2013). Environmentally friendly products from plants in the control of biodeteriogen agents. Natural Products, 9(5), 167-174.

Dharmawan, J., Kasapis, S., Curran, P., \& Johnson, J. R. (2007). Characterization of volatile compounds in selected citrus fruits from Asia. Part I: Freshly-squeezed juice. Flavour and Fragrance Journal, 22(3), 228-232. https://doi.org/10. 1002/ffj.

Fernández, M. A., Barberia Roque, L., Gámez Espinosa, E., Deyá, C., \& Bellotti, N. (2020). Organo-montmorillonite with biogenic compounds to be applied in antifungal coatings. Applied Clay Science. https://doi.org/10.1016/j. clay.2019.105369.

Gabriel, K. T., Kartforosh, L., Crow, S. A., \& Cornelison, C. T. (2018). Antimicrobial activity of essential oils against the fungal pathogens ascosphaera apis and pseudogymnoascus destructans. Mycopathologia, 183(6), 921-934. https://doi. org/10.1007/s11046-018-0298-x.

Homa, M., Fekete, I., Böszörményi, A., Singh, Y., Selvam, K., Shobana, C., et al. (2015). Antifungal effect of essential oils against fusarium keratitis isolates. Planta Medica,
81(14), 1277-1284. https://doi.org/10.1055/s-00351546272.

Hu, Y., Zhang, J., Kong, W., Zhao, G., \& Yang, M. (2017). Mechanisms of antifungal and anti-aflatoxigenic properties of essential oil derived from turmeric (Curcuma longa L.) on Aspergillus flavus. Food Chemistry, 220, 1-8. https:// doi.org/10.1016/j.foodchem.2016.09.179.

ISO. (1984). ISO 6571:1984 Spices, condiments and herbs Determination of volatile oil content. https://www.iso.org/ standard/12976.html

Jain, A., \& Parihar, D. K. (2018). Antibacterial, biofilm dispersal and antibiofilm potential of alkaloids and flavonoids of Curcuma. Biocatalysis and Agricultural Biotechnology, 16, 677-682. https://doi.org/10.1016/j.bcab.2018.09.023.

James M. Jay, Martin J. Loessner, D. A. G. (2005). Modern Food Microbiology (7th ed.). New York: Chapman and Hall. https://www.academia.edu/37575774/James_M._ Jay_Martin_J._Loessner_David_A._Golden-Modern_ Food_Microbiology_7th_Edition_Food_Science_Texts_ Series_20.pdf

Ji, H., Kim, H., Beuchat, L. R., \& Ryu, J. H. (2019). Synergistic antimicrobial activities of essential oil vapours against Penicillium corylophilum on a laboratory medium and beef jerky. International Journal of Food Microbiology, 291, 104-110. https://doi.org/10.1016/j.ijfoodmicro.2018.11. 023.

Levinskaite, L. (2012). Susceptibility of food-contaminating Penicillium genus fungi to some preservatives and disinfectants. Annals of agricultural and environmental medicine: AAEM, 19(1), 85-9. https://www.ncbi.nlm.nih.gov/ pubmed/22462451

Malta-Vacas, J., Sabino, R., Viegas, S., \& Viegas, C. (2012), Occupational exposure to toxigenic fungi from Aspergillus flavus complex. Toxicology Letters, 211(2012), S208. https://doi.org/10.1016/j.toxlet.2012.03.746.

Mishra, R., Gupta, A. K., Kumar, A., Lal, R. K., Saikia, D., \& Chanotiya, C. S. (2018). Genetic diversity, essential oil composition, and in vitro antioxidant and antimicrobial activity of Curcuma longa L. germplasm collections. Journal of Applied Research on Medicinal and Aromatic Plants, 10(June), 75-84. doi:https://doi.org/10.1016/j. jarmap.2018.06.003

Mutua, F., Lindahl, J., \& Grace, D. (2019). Availability and use of mycotoxin binders in selected urban and Peri-urban areas of Kenya. Food Security, 11(2), 359-369. https://doi. org/10.1007/s12571-019-00911-4.

Naddafi, K., Nabizadeh, R., Rostamy, R., Ebrahimi Kalan, M., Hassanvand, M. S., \& Fazlzadeh, M. (2019). Indoor air quality in waterpipe cafés: exposure level to particulate matter. Environmental Science and Pollution Research. https://doi.org/10.1007/s11356-019-05546-8.

Perczak, A., Gwiazdowska, D., Marchwińska, K., Juś, K., Gwiazdowski, R., \& Waśkiewicz, A. (2019). Antifungal activity of selected essential oils against Fusarium culmorum and $F$. graminearum and their secondary metabolites in wheat seeds. Archives of Microbiology. https://doi. org/10.1007/s00203-019-01673-5.

Pibiri, M., Goel, A., Vahekeni, N., \& Roulet, C. (2006). Indoor air purification and ventilation systems sanitation with essential oils. International Journal of Aromatherapy, 
16(3-4), 149-153. https://doi.org/10.1016/j.ijat.2006.10. 002.

Quintero-Mora, M. L., Londoño-Orozco, A., Hernández-Hernández, F., Manzano-Gayosso, P., López-Martínez, R., Soto-Zárate, C. I., et al. (2008). Efecto de extractos de propóleos mexicanos de Apis mellifera sobre el crecimiento in vitro de Candida albicans. Revista Iberoamericana de Micología, 25(1), 22-26. https://doi.org/10.1016/ S1130-1406(08)70006-8.

Restrepo, S., Franco, A. E., \& Vargas, N. (2012). Biología hongos (1ra ed.). Colombia: Ediciones Uniandes.

Rojas, T. I., \& Aira, M. J. (2012). Fungal biodiversity in indoor environments in Havana Cuba. Aerobiologia, 28(3), 367-374. https://doi.org/10.1007/s10453-011-9241-z.

Sabino, R., Burco, J., Valente, J., Veríssimo, C., Clemons, K. V., Stevens, D. A., \& Tell, L. A. (2019). Molecular identification of clinical and environmental avian Aspergillus isolates. Archives of Microbiology, 201(2), 253-257. https://doi.org/10.1007/s00203-019-01618-y.

Tyagi, A. K., Malik, A., Gottardi, D., \& Guerzoni, M. E. (2012). Essential oil vapour and negative air ions: A novel tool for food preservation. Trends in Food Science \& Technology, 26(2), 99-113. https://doi.org/10.1016/j.tifs.2012.02.004.

Valdés-Pérez, O., Borrego-Alonso, S., Vivar-González, I., Anaya-Villalpanda, M., \& Molina-Veloso, A. (2016). Actividad antifúngica del aceite esencial de clavo de olor en el control del biodeterioro fúngico de documentos. $R e$ vista CENIC Ciencias Biológicas, 47(2), 78-85.

Wang, H., Yang, Z., Ying, G., Yang, M., Nian, Y., Wei, F., \& Kong, W. (2018). Antifungal evaluation of plant essential oils and their major components against toxigenic fungi. Industrial Crops and Products, 120, 180-186. https://doi. org/10.1016/j.indcrop.2018.04.053.

Wang, P., Chang, P.-K., Kong, Q., Shan, S., \& Wei, Q. (2019). Comparison of aflatoxin production of Aspergillus flavus at different temperatures and media: Proteome analysis based on TMT. International Journal of Food Microbiology, 310, 108313. https://doi.org/10.1016/j.ijfoodmicro.2019. 108313.

Windarsih, A., Rohman, A., \& Swasono, R. T. (2019). Application of $1 \mathrm{H}-\mathrm{NMR}$ based metabolite fingerprinting and chemometrics for authentication of Curcuma longa adulterated with C. heyneana. Journal of Applied Research on Medicinal and Aromatic Plants, (April 2018), 100203. https://doi.org/10.1016/j.jarmap.2019.100203

Zorzi Tomazoni, E., Schiavo Griggio, G., Pessin Broilo, E., da Silva Ribeiro, R. T., Gonçalves Soares, G. L., \& Schwambach, J. (2018). Screening for inhibitory activity of essential oils on fungal tomato pathogen Stemphylium solani Weber. Biocatalysis and Agricultural Biotechnology, 16(September 2017), 364-372. https://doi.org/10. 1016/j.bcab.2018.08.012 